\title{
Fabrication of Novel 2D NiO Nanosheet Branched on 1D-ZnO Nanorod Arrays for Gas Sensor Application
}

\author{
Le Thuy Hoa, Huynh Ngoc Tien, and Seung Hyun Hur \\ School of Chemical Engineering and Bioengineering, University of Ulsan, Daehak-ro 102, Nam-gu, Ulsan 680-749, Republic of Korea \\ Correspondence should be addressed to Seung Hyun Hur; shhur@ulsan.ac.kr
}

Received 4 August 2014; Revised 27 October 2014; Accepted 28 October 2014; Published 13 November 2014

Academic Editor: Santanu K. Maiti

Copyright (C) 2014 Le Thuy Hoa et al. This is an open access article distributed under the Creative Commons Attribution License, which permits unrestricted use, distribution, and reproduction in any medium, provided the original work is properly cited.

\begin{abstract}
Fabrication of 3D structures composed of 1D n-type $\mathrm{ZnO}$ nanorods (NRs) and 2D p-type NiO nanosheets (NSs) by a low-cost, lowtemperature, and large-area scalable hydrothermal process and its use in highly sensitive $\mathrm{NO}_{2}$ gas sensors were studied. The $\mathrm{p}$ - $\mathrm{n}$ heterojunctions formed by $\mathrm{NiO}-\mathrm{ZnO}$ interfaces as well as large area two-dimensional $\mathrm{NiO} \mathrm{NSs}$ themselves increased the adsorption of $\mathrm{NO}_{2}$. Moreover, the charge transfer between $\mathrm{NiO}$ and $\mathrm{ZnO}$ enhanced the responsivity and sensitivity of $\mathrm{NO}_{2}$ sensing even at a concentration of $1 \mathrm{ppm}$. The 30-min $\mathrm{NiO}$ NS growth on $\mathrm{ZnO}$ NRs in the hybrid sensor showed the highest sensitivity due to the formation of optimum p-n heterojunctions between $\mathrm{ZnO}$ NRs and NiO NSs for gas adsorption and carrier transport. Low responsivity toward reducing gases was also observed.
\end{abstract}

\section{Introduction}

Among various metal oxide semiconductors, zinc oxide $(\mathrm{ZnO})$ has been used extensively due to its beneficial electrical properties such as wide band gap $(3.37 \mathrm{eV})$ and large binding energy $(60 \mathrm{meV})$. When hybridized with other materials, $\mathrm{ZnO}$ showed unique properties that can be used effectively for many types of electronic devices including gas sensors $[1,2]$, solar cells $[3,4]$, and UV sensors $[5,6]$. Moreover, it can be easily grown by hydrothermal methods in the form of nanostructures such as nanorods and nanowires that can exhibit enhanced properties due to increased surface area to volume ratios. Due to its excellent resistance to various chemicals, nickel oxide $(\mathrm{NiO})$ has been widely explored for gas sensors $[7,8]$, supercapacitors $[9,10]$, electrochromic devices [11, 12], and lithium ion batteries [13, 14]. A wide range of $\mathrm{NiO}$ nanostructures, such as thin films $[15,16]$, nanotubes [17, 18], and flake-like structures [19], can be formed by sputtering methods [20, 21], sol-gel processes $[22,23]$, and hydrothermal synthesis [24, 25]. Recent studies also demonstrated that the hybrid structures composed of $\mathrm{NiO}$ nanotubes and $\mathrm{ZnO}$ shells exhibited highly improved hydrogen sulfide $\left(\mathrm{H}_{2} \mathrm{~S}\right)$ sensing properties by the formation of heterointerfaces [26]. In our previous work we showed that optimized hybrid structures of $\mathrm{NiO}$ and $\mathrm{ZnO}$ can be effectively used as optical sensors due to improved charge transfer and decreased recombination of excitons.

In this paper, the 3D hybrid structures composed of ntype $1 \mathrm{D} \mathrm{ZnO}$ nanorods (NRs) and p-type 2D NiO nanosheets (NSs) with different $\mathrm{NiO}$ growth times were fabricated using low-cost and easy hydrothermal methods (Figure 7). These were used to detect toxic gas, such as nitrogen oxide $\left(\mathrm{NO}_{2}\right)$, which has a characteristic sharp, biting odor and is regarded as a prominent air pollutant. Due to the charge transfer between the two nanostructures as well as increased adsorption sites formed by large-area $2 \mathrm{D} \mathrm{NiO} \mathrm{NSs}$ and electron-depleted p-n junctions, the $\mathrm{NiO} \mathrm{NS} / \mathrm{ZnO}$ NR hybrid structures exhibited improved $\mathrm{NO}_{2}$ sensing properties. At optimized conditions, the hybrid structures showed a 2800 fold higher sensitivity than pure $\mathrm{ZnO}$ NRs and pure $\mathrm{NiO}$ NSs, even at very low $\mathrm{NO}_{2}$ concentrations (1 ppm). They also exhibited good selectivity toward $\mathrm{NO}_{2}$ when other gases, including $\mathrm{H}_{2}, \mathrm{NH}_{3}$, and $\mathrm{H}_{2} \mathrm{~S}$, were tested and compared.

\section{Experimental}

The hybrid structure was fabricated step by step as described in our previous study [27]. 


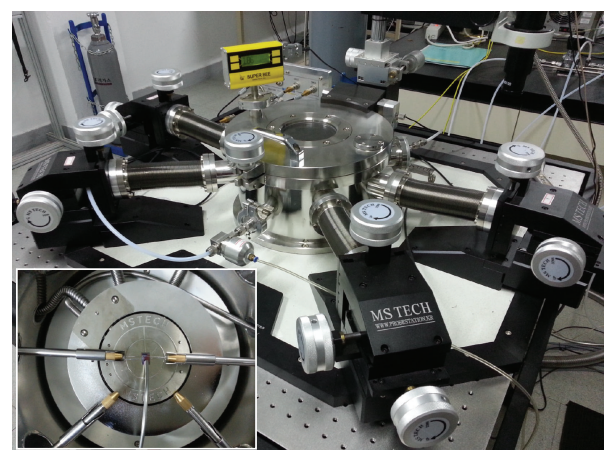

FIGURE 1: The MST-5000 gas sensor system (MST-5000, MS-Tech) and the chamber equipped with a heating plate and probes (inset), gas flow was controlled precisely by mass flow controllers, and nitrogen was used as a carrier gas.

2.1. Growth of $\mathrm{ZnO}$ NRs. The primary step is growing vertically aligned $\mathrm{ZnO} \mathrm{NRs}$ on the sensing electrode via a hydrothermal process. In brief, diethanolamine $\left(\mathrm{HN}\left(\mathrm{CH}_{2} \mathrm{CH}_{2} \mathrm{OH}\right)_{2}\right.$, Sigma-Aldrich) was added slowly into the mixed solution, which was composed of zinc acetate dehydrate $\left(\mathrm{Zn}\left(\mathrm{CH}_{3} \mathrm{COO}\right)_{2} \cdot 2 \mathrm{H}_{2} \mathrm{O} 98 \%\right.$, Sigma-Aldrich) and 2-methoxyethanol $\left(\mathrm{CH}_{3} \mathrm{OC}_{2} \mathrm{H}_{5} \mathrm{OH}\right.$, Sigma-Aldrich), under continuous magnetic stirring at $70^{\circ} \mathrm{C}$ for $2 \mathrm{~h}$. Then, the solution was spin-coated onto the sensing electrode patterned $\mathrm{SiO}_{2} / \mathrm{Si}$ wafer and annealed in air at $400^{\circ} \mathrm{C}$ for $4 \mathrm{~h}$. $\mathrm{ZnO}$ NRs were grown by exposing the prepared seed layer to the mixed aqueous solution of zinc nitrate hexahydrate $0.02 \mathrm{M}\left(\mathrm{Zn}\left(\mathrm{NO}_{3}\right)_{2} \cdot 6 \mathrm{H}_{2} \mathrm{O}\right.$, Sigma-Aldrich) and hexamethylenetetramine $0.02 \mathrm{M}\left(\mathrm{C}_{6} \mathrm{H}_{12} \mathrm{~N}_{4}\right.$, Sigma-Aldrich $)$ at $90^{\circ} \mathrm{C}$ for $5 \mathrm{~h}$. $\mathrm{ZnO} \mathrm{NRs}$ were rinsed with deionized water several times and dried in a vacuum oven before the next steps.

2.2. Growth of $\mathrm{NiO} N S$ s. To grow $\mathrm{NiO} \mathrm{NSs}$ on the $\mathrm{ZnO}$ NR surface, the $\mathrm{Ni}$ seed solution was first prepared by mixing nickel acetate tetrahydrate $\left(\mathrm{Ni}\left(\mathrm{OCOCH}_{3}\right)_{2} \cdot 4 \mathrm{H}_{2} \mathrm{O}\right.$, Sigma-Aldrich) with 2-methoxyethanol $\left(\mathrm{CH}_{3} \mathrm{OCH}_{2} \mathrm{CH}_{2} \mathrm{OH}\right.$, Sigma-Aldrich) and diethanolamine $\left(\mathrm{HN}\left(\mathrm{CH}_{2} \mathrm{CH}_{2} \mathrm{OH}\right)_{2}\right.$, Sigma-Aldrich) under continuous magnetic stirring at $70^{\circ} \mathrm{C}$ for $2 \mathrm{~h}$. Then, the mixed solution was spin-coated onto the $\mathrm{ZnO} \mathrm{NRs}$ and annealed in air at $400^{\circ} \mathrm{C}$ for $4 \mathrm{~h}$ to form a $\mathrm{Ni}$ seed layer. Next, the $\mathrm{ZnO}$ NRs covered with the $\mathrm{Ni}$ seed layer were directly exposed to a mixed aqueous solution of nickel nitrate hexahydrate $0.02 \mathrm{M}\left(\mathrm{Ni}\left(\mathrm{NO}_{3}\right)_{2} \cdot 6 \mathrm{H}_{2} \mathrm{O}\right.$ $98 \%$, Sigma-Aldrich) and hexamethylenetetramine $0.02 \mathrm{M}$ $\left(\mathrm{C}_{6} \mathrm{H}_{12} \mathrm{~N}_{4}\right.$, Sigma-Aldrich $)$ at $90^{\circ} \mathrm{C}$ to grow NiO NSs. Finally, $\mathrm{NiO} \mathrm{NSs} / \mathrm{ZnO}$ NRs were rinsed and annealed in air at $400^{\circ} \mathrm{C}$ for $4 \mathrm{~h}$.

2.3. Instrumental Analysis. The structures of $\mathrm{NiO} \mathrm{NSs} / \mathrm{ZnO}$ NRs, $\mathrm{NiO} \mathrm{NSs}$, and $\mathrm{ZnO} \mathrm{NRs}$ were characterized by $\mathrm{X}$ ray diffraction (XRD) and field-emission scanning electron microscopy (FE-SEM) after thin film growth on the $\mathrm{SiO}_{2} / \mathrm{Si}$ wafer. Gas sensing properties were measured using a MST5000 chamber (MS-Tech, Figure 1) at $200^{\circ} \mathrm{C}$. Gas flow was precisely controlled using a mass flow controller (GMC 1200,
ATOVAC) and nitrogen $\left(\mathrm{N}_{2}\right)$ was used as a carrier gas. A semiconductor parameter analyzer (Hewlett-Packard-4155A) was used to measure the resistance of sensing devices.

\section{Results and Discussion}

The morphology change of $\mathrm{NiO}$ NSs on the $\mathrm{ZnO}$ NRs at different $\mathrm{NiO}$ growth times was investigated and is shown in Figure 2. We can only infer the growth of $\mathrm{NiO} \mathrm{NSs}$ by the increased roughness of $\mathrm{ZnO} \mathrm{NRs}$ or some fibrillike structures between $\mathrm{ZnO} \mathrm{NRs}$ at short growth times (Figures 2(a) and 2(b)). Instead, the 3D networks of $\mathrm{NiO}$ NSs between ZnO NRs are clearly observed after longer growth times, which implies that various morphologies of $\mathrm{NiO} \mathrm{NS} / \mathrm{ZnO} \mathrm{NR}$ hybrid structures that have different $\mathrm{Ni} / \mathrm{Zn}$ ratios can be realized by changing the $\mathrm{NiO}$ growth time.

In order to verify the crystal structure and phase purity of the samples, XRD analysis was used, and these results are shown in Figure 3. NiO NSs exhibit three characteristic peaks at $37.30^{\circ}, 43.28^{\circ}$, and $65.23^{\circ}$, which, respectively, correspond to the (111), (200), and (220) planes of bunsenite structure $\mathrm{NiO}$ [28]. ZnO NR shows peaks at $31.87^{\circ}, 34.54^{\circ}, 56.81^{\circ}$, and $67.23^{\circ}$, which, respectively, correspond to the (100), (002), (110), and (201) planes of hexagonal structure of $\mathrm{ZnO}$ [29]. The intensity ratio of $I_{\mathrm{Ni}(220)} / I_{\mathrm{Zn}(002)}$ was increased from 0.2538 to 4.4134 as the $\mathrm{NiO}$ growth time increased from $5 \mathrm{~min}$ to $60 \mathrm{~min}$, which indicates continuous growth of $\mathrm{NiO} \mathrm{NSs}$ on the $\mathrm{ZnO}$ NRs.

The atomic composition and TEM image were shown in Figure 4 . Both the $\mathrm{Zn}$ and $\mathrm{Ni}$ atoms were observed in the energy dispersive X-ray (EDX) analysis and ZnO NR covered with $\mathrm{NiO}$ NS was also clearly observed in the TEM image.

The $I-V$ characteristics of $\mathrm{ZnO}$ NRs, $\mathrm{NiO}$ NSs, and $\mathrm{NiO}$ $\mathrm{NSs} / \mathrm{ZnO} \mathrm{NRs}$ were measured to investigate the electrical resistance of each sample. The electrodes used in this study were prepared following our previous study [27]. As shown in Figure 5, after decorating the $\mathrm{NiO}$ NSs with $\mathrm{ZnO}$ NRs, the conductance was decreased due to the formation of local electron depletion layers at the heterojunctions between $\mathrm{p}$ type $\mathrm{NiO}$ and $\mathrm{n}$-type $\mathrm{ZnO}$. The electrical resistivity of $\mathrm{ZnO}$ nanorods calculated using the thickness of the $\mathrm{ZnO}$ seed layer, as shown in the inset of Figure 4, was approximately $4.14 \times 10^{-5} \Omega \cdot \mathrm{cm}$, which was higher than that of a previous report because hydrothermal synthesis was used in this study [28].

$\mathrm{NO}_{2}$ responsivity $\left(\mathrm{RS},\left(R_{g}-R_{a}\right) / R_{g}(\%)\right)$ and sensitivity (RS/gas concentration (ppm)) of the NiO NSs/ZnO NRs and $\mathrm{NiO}$ NSs alone were measured at low levels of $\mathrm{NO}_{2}$, where $R_{a}$ and $R_{g}$ are the resistances of the sensing layer measured in the atmosphere of only $\mathrm{N}_{2}$ and $\mathrm{NO}_{2} / \mathrm{N}_{2}$ gas mixture, respectively. As shown in Figure 6, the $\mathrm{NiO} \mathrm{NS} / \mathrm{ZnO} \mathrm{NR}$ hybrid structure exhibited around a 6-fold higher responsivity and 9-fold higher sensitivity than those of $\mathrm{NiO}$ NSs, which has a large enough adsorption area. The sensitivity obtained in this study of $3.4026 \mathrm{ppm}^{-1}$ from the $\mathrm{NiO} \mathrm{NS}$ (30 min growth time)/ZnO NR sample is three orders ( 2800-fold) higher than that of pure $\mathrm{ZnO}$ NRs and even one order ( $\sim 20$-fold) higher than that of $0-\mathrm{D} \mathrm{CuO}$ nanoparticles decorated with $1 \mathrm{D} \mathrm{ZnO} \mathrm{NR}$ 


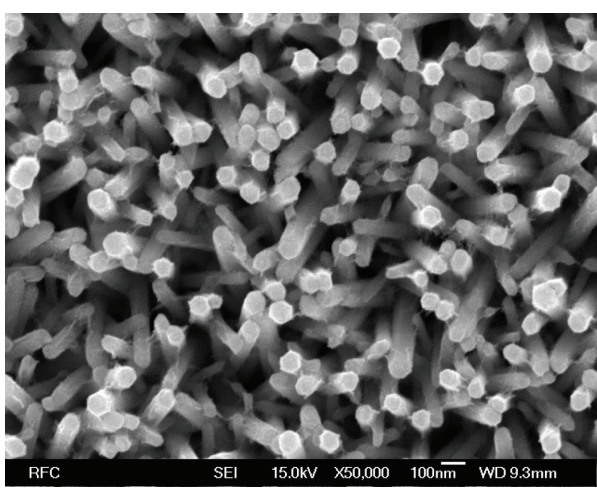

(a)

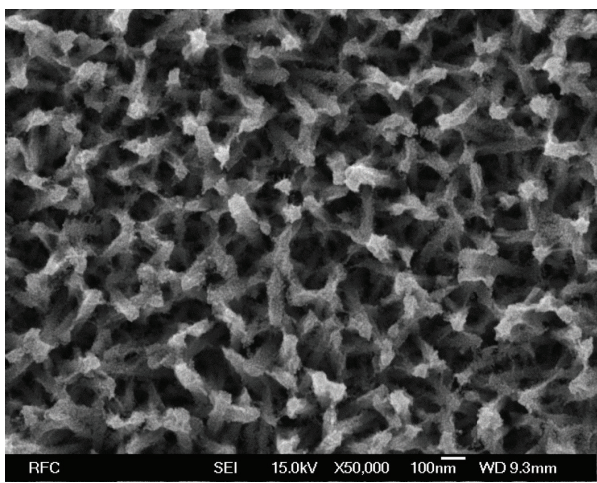

(c)

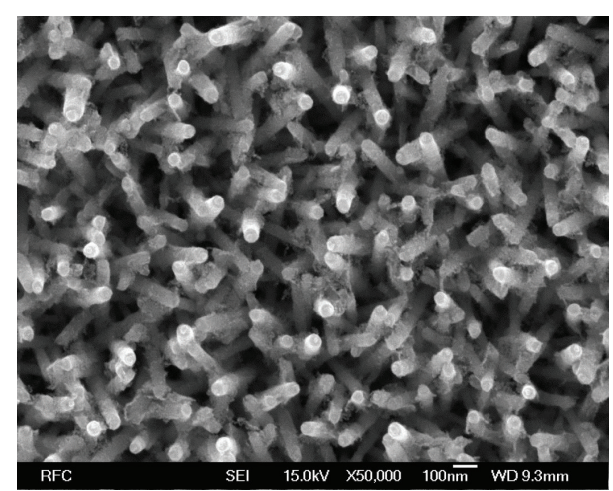

(b)

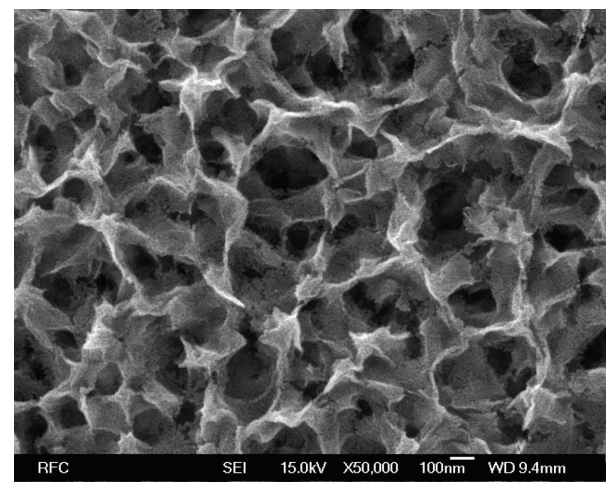

(d)

FIgURE 2: SEM images of NiO NSs grown on ZnO NRs for (a) $5 \mathrm{~min}$, (b) $15 \mathrm{~min}$, (c) $45 \mathrm{~min}$, and (d) $60 \mathrm{~min}$.

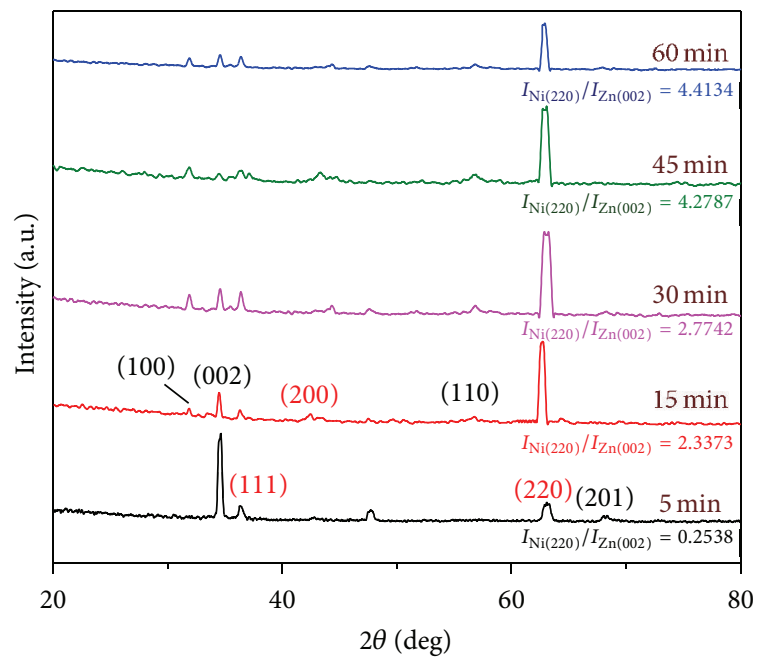

FIGURE 3: XRD spectra of $\mathrm{NiO}$ NSs grown on $\mathrm{ZnO}$ NRs at various $\mathrm{NiO}$ NS growth times from $5 \mathrm{~min}$ to $60 \mathrm{~min}$.

that were reported previously [29]. The fast response time of $\mathrm{NiO} \mathrm{NS} / \mathrm{ZnO}$ NR than that of $\mathrm{NiO}$ NS was observed, which can be due to the high amount of p-n junction sites that can effectively adsorb $\mathrm{NO}_{2}$ molecules. It is also interesting to note that the $\mathrm{NO}_{2}$ sensitivity increased initially as the $\mathrm{NiO} \mathrm{NS}$ growth time increased until $30 \mathrm{~min}$ then the $\mathrm{NO}_{2}$ sensitivity decreased gradually, which indicates the presence of an optimum ratio of $\mathrm{NiO}$ NSs and $\mathrm{ZnO}$ NRs. In turn, excess growth of $\mathrm{NiO} \mathrm{NSs}$ will cover the whole $\mathrm{ZnO} \mathrm{NR}$ surface and thus synergetic effects between $\mathrm{NiO}$ NSs and ZnO NRs cannot be expected.

The improved $\mathrm{NO}_{2}$ response and sensitivity of the $\mathrm{NiO}$ $\mathrm{NS} / \mathrm{ZnO}$ NR hybrid structure can be explained as follows. First, increased surface area after $\mathrm{NiO}$ NS growth on $\mathrm{ZnO}$ provided a larger $\mathrm{NO}_{2}$ adsorption area. In addition, the numerous electron-depletion layers that formed at the $\mathrm{p}$ $\mathrm{NiO} \mathrm{NS}$ and $\mathrm{n}-\mathrm{ZnO}$ heterojunction region attracted the gases more than bare $\mathrm{ZnO}$ NRs or $\mathrm{NiO}$ NSs alone, which results in more $\mathrm{NO}_{2}$ adsorption even at low concentration [30]. Another important fact is the charge transfer between $\mathrm{p}$ type $\mathrm{NiO} \mathrm{NSs}$ and n-type $\mathrm{ZnO}$ NRs [28]. When $\mathrm{NO}_{2}$ gas is exposed to the $\mathrm{NiO} \mathrm{NSs}$, the $\mathrm{NO}_{2}$ first reacts with the adsorbed $\mathrm{O}^{-}$ions on $\mathrm{NiO}$ as $\mathrm{NO}_{2}$ has higher electron affinity than that of the preadsorbed oxygen [31]; this results in the generation of holes on $\mathrm{NiO}$ surfaces:

$$
\begin{gathered}
\mathrm{NO}_{2} \text { (gas) } \longrightarrow \mathrm{NO}_{2} \text { (ads) } \\
\mathrm{NO}_{2} \text { (ads) } \longrightarrow \mathrm{NO}_{2}{ }^{-} \text {(ads) }+\mathrm{h}^{+}
\end{gathered}
$$

Then, the transfer of holes from p-type $\mathrm{NiO}$ to n-type $\mathrm{ZnO}$ (loss of electrons of $\mathrm{n}$-type $\mathrm{ZnO}$ ) leads to a resistance increase of the $\mathrm{ZnO}$ seed layer that carries charges between two electrodes. Without $\mathrm{NiO}-\mathrm{ZnO}$ heterojunctions ( $\mathrm{NiO}$ 


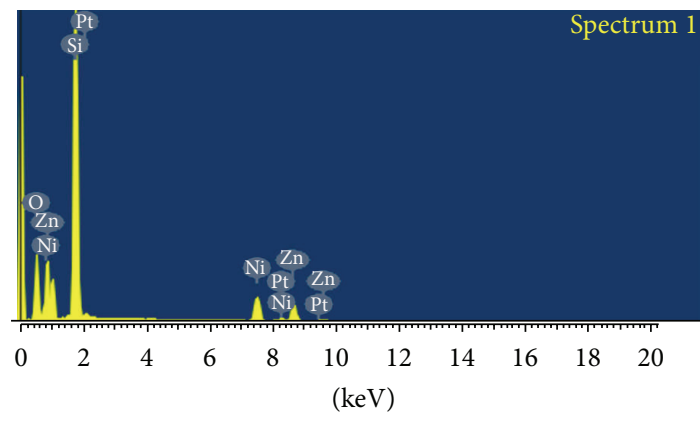

Full scale 10541 cts cursor: $0.000 \mathrm{keV}$

(a)

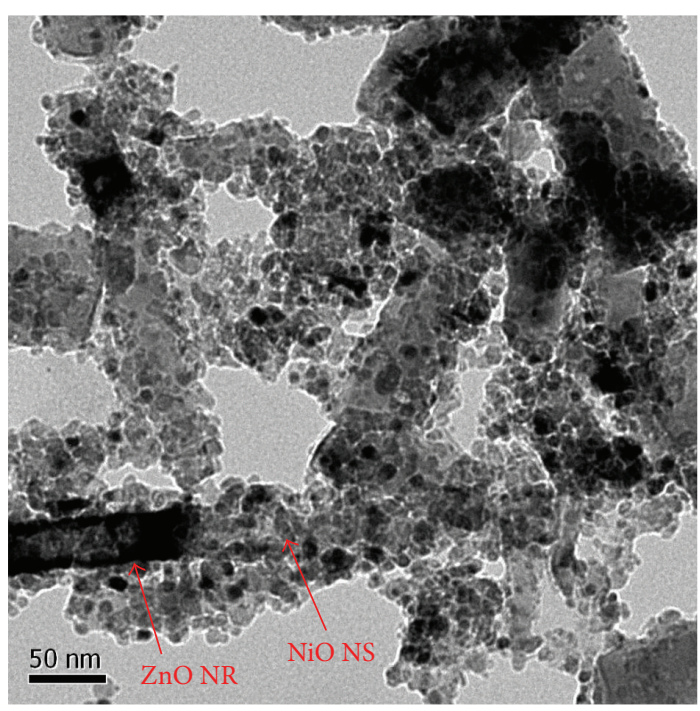

(b)

Figure 4: (a) EDX spectrum of NiO NSs/ZnO NRs and (b) TEM image of $\mathrm{ZnO} \mathrm{NR}$ covered with $\mathrm{NiO}$ NS.

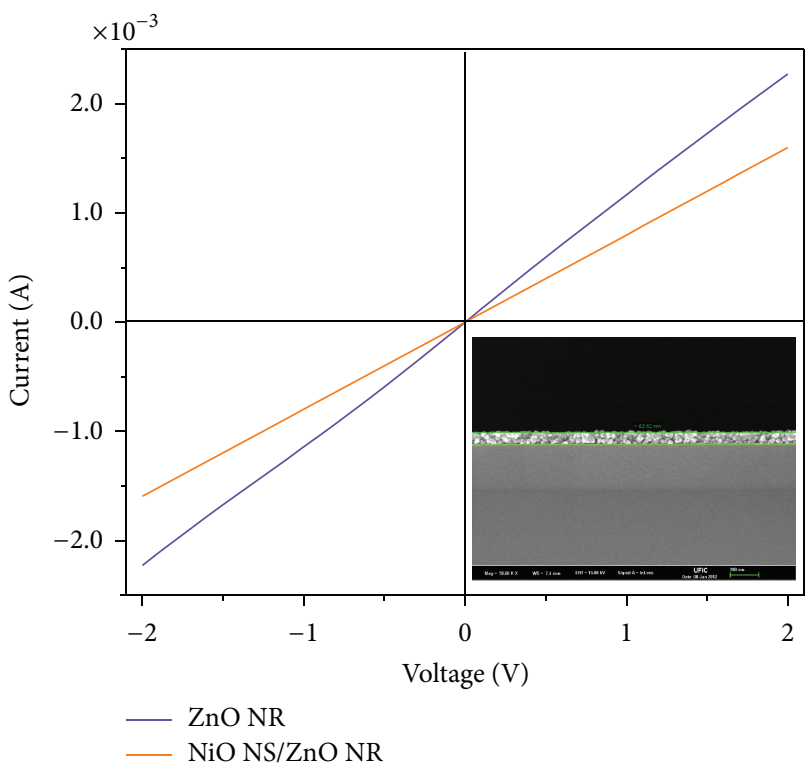

FIGURE 5: $I-V$ curves of $\mathrm{ZnO}$ NRs and $\mathrm{NiO} N S s / Z n O$ NRs. The inset shows a cross-sectional SEM image of $\mathrm{ZnO}$ seed layer. alone), there will be hole accumulation on the NiO surface, which will cause low responsivity due to the suppressed further adsorption of $\mathrm{NO}_{2}$. On the other hand, in the presence of $\mathrm{p}-\mathrm{n}$ heterojunctions, hole transfer from $\mathrm{NiO}$ NSs to $\mathrm{ZnO}$ NRs will prevent the accumulation of holes in $\mathrm{NiO} \mathrm{NSs}$, thus maintaining the adsorption of $\mathrm{NO}_{2}$. This will enhance both the responsivity and sensitivity of sensing layers.

The responsivity of fabricated $\mathrm{NiO} \mathrm{NS} / \mathrm{ZnO} \mathrm{NR}$ gas sensors toward reducing gases, such as $\mathrm{H}_{2} \mathrm{~S}, \mathrm{H}_{2}$, and $\mathrm{NH}_{3}$, was also investigated. As shown in Figure 6, the responsivity for reducing gases was lower than that for $\mathrm{NO}_{2}$ gas, which can be due to the low catalytic effect during the adsorption of reducing gases [32]. As described in the following reaction, when reducing gases are adsorbed onto the metal oxide surface they are oxidized through the reaction with preadsorbed oxygen ions. Due to the low dissociative chemisorption of hydrogen by the $\mathrm{NiO}$, there is less electron generation, which results in the lower responsivity of $\mathrm{NiO} \mathrm{NS} / \mathrm{ZnO} \mathrm{NR}$ sensors for reducing gases than that for $\mathrm{NO}_{2}$. The surface modification by $\mathrm{Pt}$, which has excellent $\mathrm{H}_{2}$ adsorption and catalytic dissociation ability, can enhance the responsivity of $\mathrm{NiO}$-based sensors toward reducing gases [33]:

$$
\mathrm{H}_{2} \text { (gas) }+\mathrm{O}^{-} \text {(ads) } \longrightarrow \mathrm{H}_{2} \mathrm{O}+\mathrm{e}^{-}
$$

The highest responsivity at $30 \mathrm{~min}$ of $\mathrm{NiO} \mathrm{NS}$ growth indicates the similar synergetic effect of charge transfer between $\mathrm{NiO}$ NSs and $\mathrm{ZnO}$ NRs as the $\mathrm{NO}_{2}$ gas case. The negative responsivity of the hybrid sensor for reducing gases is due to the electron generated by the oxidation of reducing gases. Electrons transferred from the p-type $\mathrm{NiO}$ NSs to ntype $\mathrm{ZnO}$ might decrease the resistance of $\mathrm{n}$-type $\mathrm{ZnO}$, which acts as channel materials for carrier transport in the sensing devices.

\section{Conclusions}

The 3D structures composed of $1 \mathrm{D} \mathrm{ZnO}$ NRs and 2D NiO NSs were fabricated by an easy and cost-effective hydrothermal synthesis method, and these were then used for $\mathrm{NO}_{2}$ sensors. Due to the increased surface areas, formation of electron depletion layers at $\mathrm{ZnO}-\mathrm{NiO}$ heterojunctions, and effective carrier transport between two nanostructured semiconductors, the $\mathrm{NiO} \mathrm{NS} / \mathrm{ZnO} \mathrm{NR}$ sensors exhibited highly improved sensitivity toward $\mathrm{NO}_{2}$ gases over pure $\mathrm{NiO} \mathrm{NS}$ and $\mathrm{ZnO}$ NR sensors. It was also observed that at a $30 \mathrm{~min} \mathrm{NiO} \mathrm{NS}$ growth on $\mathrm{ZnO} \mathrm{NRs}$, hybrid sensors exhibited maximum $\mathrm{NO}_{2}$ sensitivity due to the formation of optimized 1D-2D p-n heterojunction hybrid structures. Due to the low dissociative chemisorption of $\mathrm{H}_{2}$ on $\mathrm{NiO}$, hybrid sensors exhibited low response toward reducing gases, which results in improved selectivity. We think that this type of $3 \mathrm{D}$ structures can be effectively used in many gas-sensing applications due to its simple fabrication process and high sensing performance. 


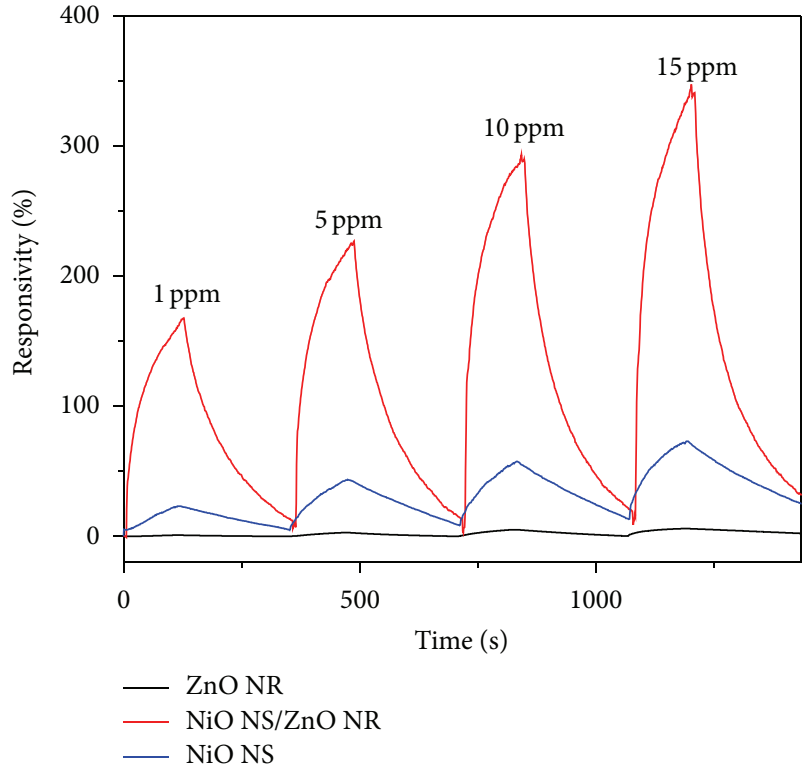

(a)

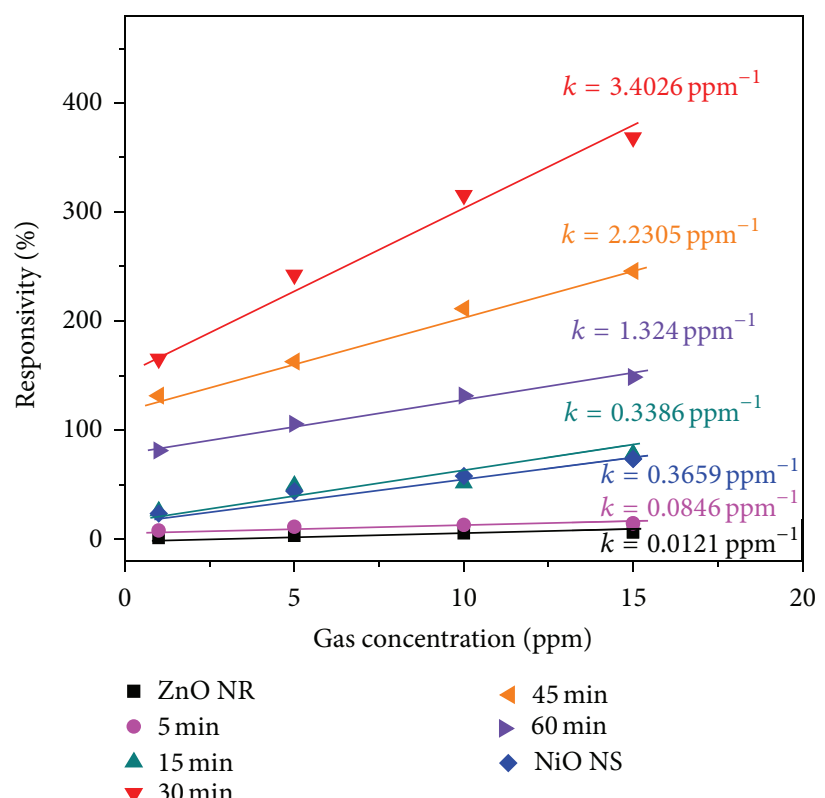

(b)

Figure 6: (a) Responsivity of pure $\mathrm{NiO} \mathrm{NSs}$ and $\mathrm{NiO} \mathrm{NSs} / \mathrm{ZnO}$ NRs at $30 \mathrm{~min} \mathrm{NiO}$ growth and (b) the sensitivity of NiO NSs/ZnO NRs at various $\mathrm{NiO}$ growth times toward various $\mathrm{NO}_{2}$ gas concentrations.

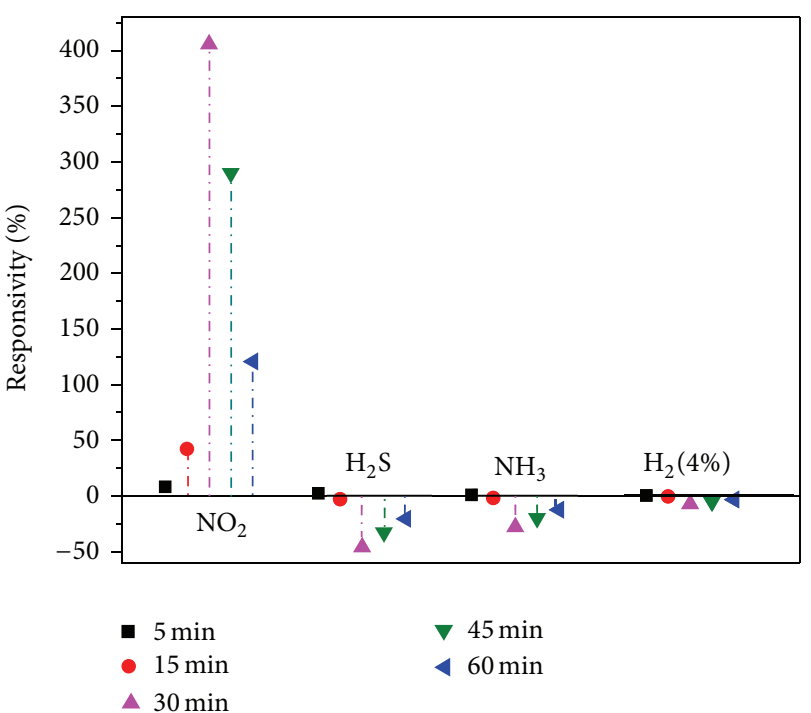

FIGURE 7: Responsivity of NiO NS/ZnO NR sensors at different $\mathrm{NiO}$ growth times under various gases. Concentrations of $\mathrm{NO}_{2}, \mathrm{H}_{2} \mathrm{~S}$, and $\mathrm{NH}_{3}$ were $100 \mathrm{ppm}$ and that of $\mathrm{H}_{2}$ was $4 \%$, respectively.

\section{Conflict of Interests}

All authors have no conflict of interests to declare. This statement is to certify that all authors have seen and approved the paper being submitted. The authors warrant that the paper is the authors' original work. The authors warrant that the paper has not received prior publication and is not under consideration for publication elsewhere. On behalf of all coauthors, the corresponding author shall bear full responsibility for the submission. This research has not been submitted for publication nor has it been published in whole or in part elsewhere.

\section{Acknowledgment}

This research was supported by the Basic Science Research Program through the National Research Foundation of Korea (NRF) funded by the Ministry of Education (2013R1A1A2A10004468).

\section{References}

[1] Q. Wan, Q. H. Li, Y. J. Chen et al., "Fabrication and ethanol sensing characteristics of $\mathrm{ZnO}$ nanowire gas sensors," Applied Physics Letters, vol. 84, no. 18, pp. 3654-3656, 2004.

[2] M.-W. Ahn, K.-S. Park, J.-H. Heo et al., "Gas sensing properties of defect-controlled $\mathrm{ZnO}$-nanowire gas sensor," Applied Physics Letters, vol. 93, no. 26, Article ID 263103, 2008.

[3] S. H. Ko, D. Lee, H. W. Kang et al., "Nanoforest of hydrothermally grown hierarchical $\mathrm{ZnO}$ nanowires for a high efficiency dye-sensitized solar cell," Nano Letters, vol. 11, no. 2, pp. 666671, 2011.

[4] K. Matsubara, P. Fons, K. Iwata et al., " $\mathrm{ZnO}$ transparent conducting films deposited by pulsed laser deposition for solar cell applications," Thin Solid Films, vol. 431-432, pp. 369-372, 2003.

[5] H. Ohta, M. Kamiya, T. Kamiya, M. Hirano, and H. Hosono, "UV-detector based on pn-heterojunction diode composed of transparent oxide semiconductors, $\mathrm{p}-\mathrm{NiO} / \mathrm{n}-\mathrm{ZnO}$," Thin Solid Films, vol. 445, no. 2, pp. 317-321, 2003. 
[6] C. S. Lao, M.-C. Park, Q. Kuang et al., "Giant enhancement in UV response of $\mathrm{ZnO}$ nanobelts by polymer surfacefunctionalization," Journal of the American Chemical Society, vol. 129, no. 40, pp. 12096-12097, 2007.

[7] I. Hotovy, V. Rehacek, P. Siciliano, S. Capone, and L. Spiess, "Sensing characteristics of $\mathrm{NiO}$ thin films as $\mathrm{NO}_{2}$ gas sensor," Thin Solid Films, vol. 418, no. 1, pp. 9-15, 2002.

[8] H. Steinebach, S. Kannan, L. Rieth, and F. Solzbacher, " $\mathrm{H}_{2}$ gas sensor performance of $\mathrm{NiO}$ at high temperatures in gas mixtures," Sensors and Actuators B: Chemical, vol. 151, no. 1, pp. 162-168, 2010.

[9] J. W. Lee, T. Ahn, J. H. Kim, J. M. Ko, and J.-D. Kim, "Nanosheets based mesoporous $\mathrm{NiO}$ microspherical structures via facile and template-free method for high performance supercapacitors," Electrochimica Acta, vol. 56, no. 13, pp. 4849-4857, 2011.

[10] J. Cheng, G.-P. Cao, and Y.-S. Yang, "Characterization of solgel-derived $\mathrm{NiO}_{x}$ xerogels as supercapacitors," Journal of Power Sources, vol. 159, no. 1, pp. 734-741, 2006.

[11] X. H. Xia, J. P. Tu, J. Zhang, X. L. Wang, W. K. Zhang, and H. Huang, "Electrochromic properties of porous $\mathrm{NiO}$ thin films prepared by a chemical bath deposition," Solar Energy Materials \& Solar Cells, vol. 92, no. 6, pp. 628-633, 2008.

[12] Z. Jiao, M. Wu, Z. Qin, and H. Xu, "The electrochromic characteristics of sol-gel-prepared $\mathrm{NiO}$ thin film," Nanotechnology, vol. 14, no. 4, pp. 458-461, 2003.

[13] B. Varghese, M. V. Reddy, Z. Yanwu et al., "Fabrication of $\mathrm{NiO}$ nanowall electrodes for high performance lithium ion battery," Chemistry of Materials, vol. 20, no. 10, pp. 3360-3367, 2008.

[14] S. A. Needham, G. X. Wang, and H. K. Liu, "Synthesis of $\mathrm{NiO}$ nanotubes for use as negative electrodes in lithium ion batteries," Journal of Power Sources, vol. 159, no. 1, pp. 254-257, 2006.

[15] K.-W. Nam, W.-S. Yoon, and K.-B. Kim, "X-ray absorption spectroscopy studies of nickel oxide thin film electrodes for supercapacitors," Electrochimica Acta, vol. 47, no. 19, pp. 32013209, 2002.

[16] P. S. Patil and L. D. Kadam, "Preparation and characterization of spray pyrolyzed nickel oxide (NiO) thin films," Applied Surface Science, vol. 199, no. 1-4, pp. 211-221, 2002.

[17] G. Malandrino, L. M. S. Perdicaro, I. L. Fragalà, R. L. Nigro, M. Losurdo, and G. Bruno, "MOCVD template approach to the fabrication of free-standing nickel(II) oxide nanotube arrays: structural, morphological, and optical properties characterization," The Journal of Physical Chemistry C, vol. 111, no. 8, pp. 32113215, 2007.

[18] H. Pang, Q. Lu, Y. Li, and F. Gao, "Facile synthesis of nickel oxide nanotubes and their antibacterial, electrochemical and magnetic properties," Chemical Communications, no. 48, pp. 7542-7544, 2009.

[19] J.-W. Lang, L.-B. Kong, W.-J. Wu, Y.-C. Luo, and L. Kang, "Facile approach to prepare loose-packed $\mathrm{NiO}$ nano-flakes materials for supercapacitors," Chemical Communications, no. 35, pp. 4213-4215, 2008.

[20] H.-L. Chen, Y.-M. Lu, and W.-S. Hwang, "Characterization of sputtered NiO thin films," Surface and Coatings Technology, vol. 198, no. 1-3, pp. 138-142, 2005.

[21] Y. M. Lu, W. S. Hwang, and J. S. Yang, "Effects of substrate temperature on the resistivity of non-stoichiometric sputtered $\mathrm{NiO}_{x}$ films," Surface and Coatings Technology, vol. 155, no. 2-3, pp. 231-235, 2002.
[22] J. L. Garcia-Miquel, Q. Zhang, S. J. Allen et al., "Nickel oxide solgel films from nickel diacetate for electrochromic applications," Thin Solid Films, vol. 424, no. 2, pp. 165-170, 2003.

[23] E. O. Zayim, I. Turhan, F. Z. Tepehan, and N. Ozer, "Sol-gel deposited nickel oxide films for electrochromic applications," Solar Energy Materials \& Solar Cells, vol. 92, no. 2, pp. 164-169, 2008.

[24] D.-B. Kuang, B.-X. Lei, Y.-P. Pan, X.-Y. Yu, and C.-Y. Su, "Fabrication of novel hierarchical $\beta-\mathrm{Ni}(\mathrm{OH})_{2}$ and $\mathrm{NiO}$ microspheres via an easy hydrothermal process," The Journal of Physical Chemistry C, vol. 113, no. 14, pp. 5508-5513, 2009.

[25] L. Wang, Y. Hao, Y. Zhao, Q. Lai, and X. Xu, "Hydrothermal synthesis and electrochemical performance of $\mathrm{NiO}$ microspheres with different nanoscale building blocks," Journal of Solid State Chemistry, vol. 183, no. 11, pp. 2576-2581, 2010.

[26] L. Xu, R. Zheng, S. Liu et al., "NiO@ZnO heterostructured nanotubes: coelectrospinning fabrication, characterization, and highly enhanced gas sensing properties," Inorganic Chemistry, vol. 51, no. 14, pp. 7733-7740, 2012.

[27] L. T. Hoa, H. N. Tien, and S. H. Hur, "A highly sensitive UV sensor composed of $2 \mathrm{D} \mathrm{NiO}$ nanosheets and $1 \mathrm{D} \mathrm{ZnO}$ nanorods fabricated by a hydrothermal process," Sensors and Actuators A: Physical, vol. 207, pp. 20-24, 2014.

[28] L. T. Hoa, H. N. Tien, V. H. Luan, J. S. Chung, and S. H. Hur, "Fabrication of a novel $2 \mathrm{D}$-graphene/2D-NiO nanosheetbased hybrid nanostructure and its use in highly sensitive $\mathrm{NO}_{2}$ sensors," Sensors and Actuators B: Chemical, vol. 185, pp. 701705, 2013.

[29] L. T. Hoa and S. H. Hur, "Highly sensitive $\mathrm{NO}_{2}$ sensors based on local $\mathrm{p}-\mathrm{n}$ heterojunctions composed of $0 \mathrm{D} \mathrm{CuO}$ nanoparticles and 1D ZnO nanorods," Physica Status Solidi (A), vol. 210, no. 6, pp. 1213-1216, 2013.

[30] C. W. Na, H.-S. Woo, I.-D. Kim, and J.-H. Lee, "Selective detection of $\mathrm{NO}_{2}$ and $\mathrm{C}_{2} \mathrm{H}_{5} \mathrm{OH}$ using a $\mathrm{Co}_{3} \mathrm{O}_{4}$-decorated $\mathrm{ZnO}$ nanowire network sensor," Chemical Communications, vol. 47, no. 18, pp. 5148-5150, 2011.

[31] N. D. Hoa and S. A. El-Safty, "Synthesis of mesoporous NiO nanosheets for the detection of toxic $\mathrm{NO}_{2}$ gas," Chemistry, vol. 17, no. 46, pp. 12896-12901, 2011.

[32] A. Borgschulte, R. J. Westerwaal, J. H. Rector, B. Dam, and R. Griessen, "Hydrogen sorption mechanism of oxidized nickel clusters," Applied Physics Letters, vol. 85, no. 21, pp. 4884-4886, 2004.

[33] I. Hotovy, J. Huran, P. Siciliano, S. Capone, L. Spiess, and V. Rehacek, "Enhancement of $\mathrm{H}_{2}$ sensing properties of NiO-based thin films with a Pt surface modification," Sensors and Actuators B: Chemical, vol. 103, no. 1-2, pp. 300-311, 2004. 

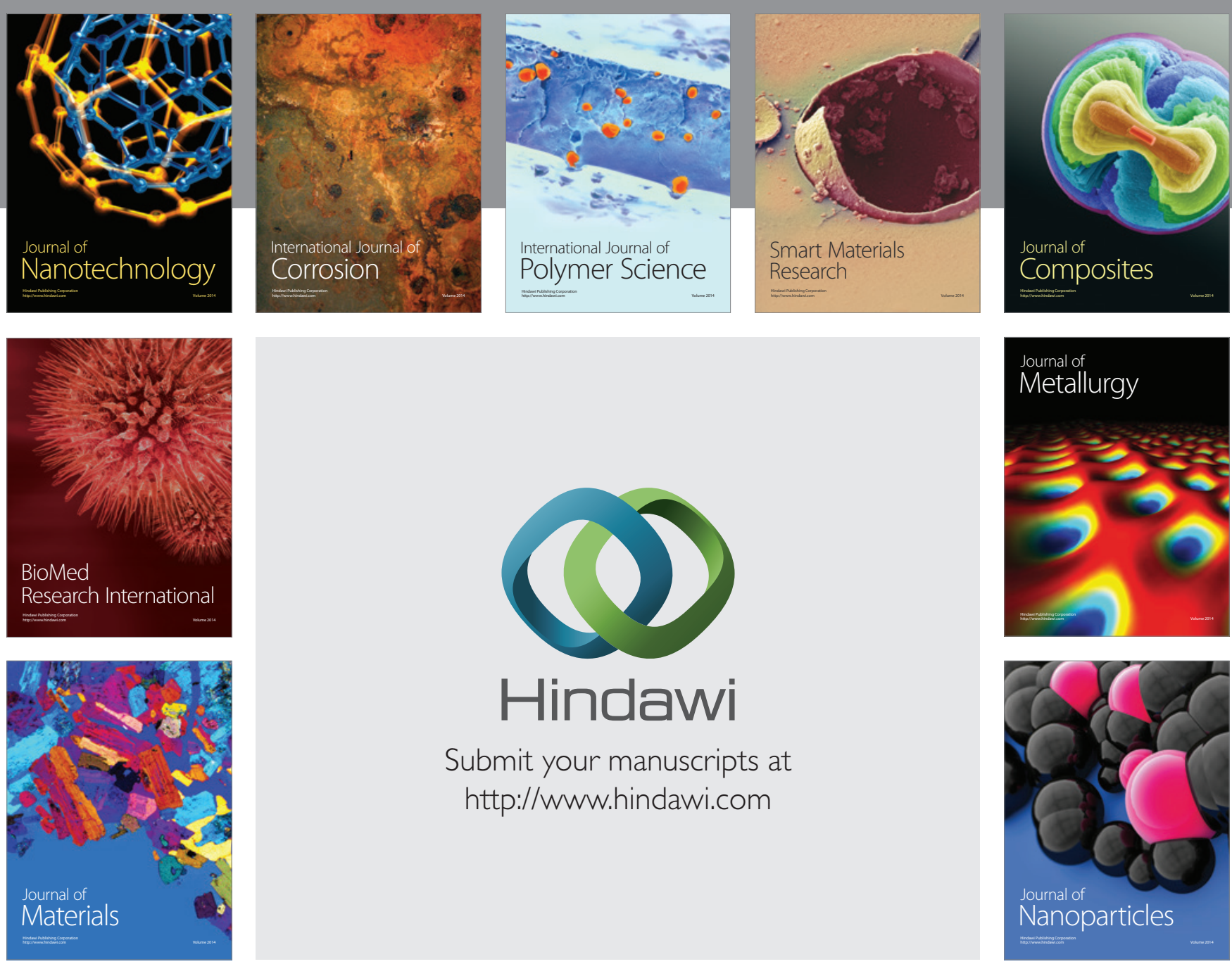

Submit your manuscripts at http://www.hindawi.com
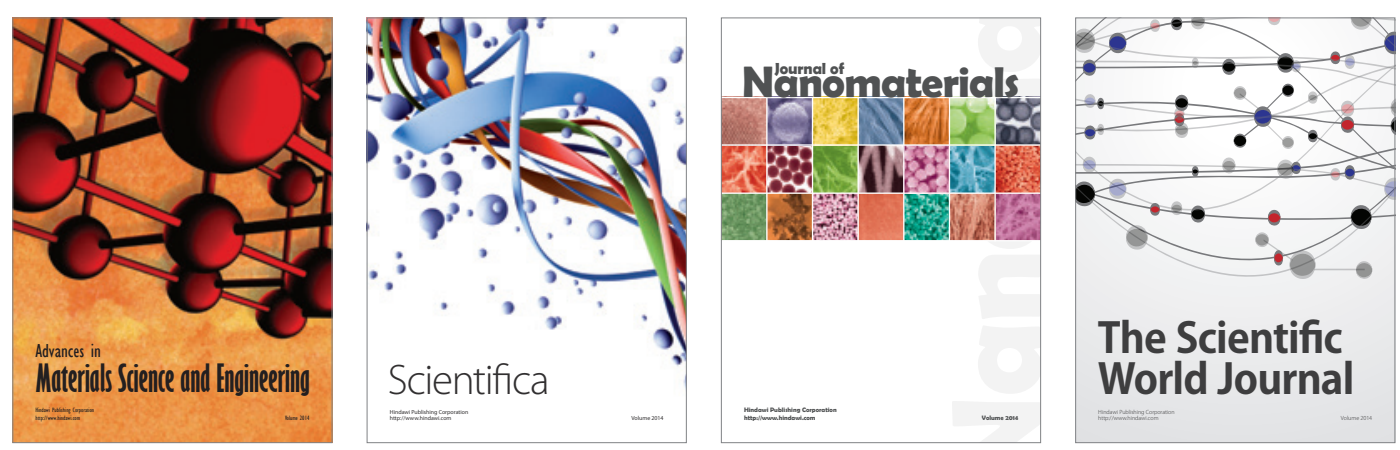

\section{The Scientific World Journal}
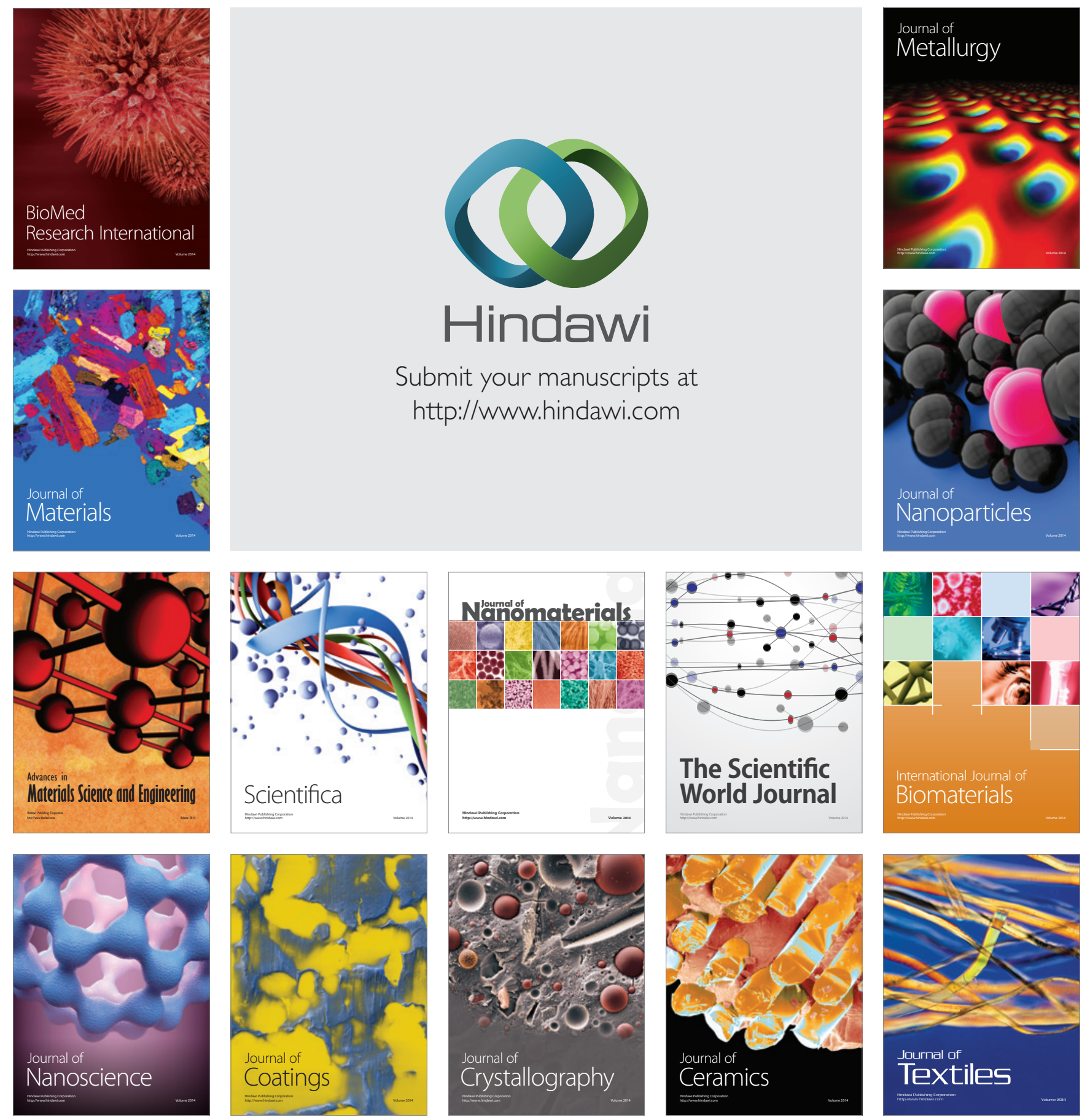